Special Section: The economies, ecologies and politics of social forestry in Indonesia Editorial Introduction

\title{
The politics, economies, and ecologies of Indonesia's third generation of social forestry: An introduction to the special section
}

\author{
Micah R. Fisher ${ }^{1,3}$, Ahmad Dhiaulhaq ${ }^{2}$, Muhammad Alif K.Sahide ${ }^{3 *}$ \\ 1 University of Hawaii at Manoa, United States \\ 2 Australian National University, Australia \\ 3 Forestry Faculty of Universitas Hasanuddin, Makassar, Indonesia; muhammad.alif@unhas.ac.id \\ * Corresponding author
}

\begin{abstract}
Although Indonesia is experiencing one of the most complex transformations of social forestry policy in the world, there is a need to step back and more closely examine the politics, ecologies, and economies that provide context for its implementation. This introduction offers a synthesis of the collection of special section submissions in Forest and Society. We begin by navigating the current social forestry moment by presenting a heuristic for identifying the discourses underpinning the rapid expansion in support of social forestry schemes. These perspectives are fragmented across four continuously contested discourses: community-first, legal-first, conservation-first, and development-first. We then contextualize the historical developments that brought social forestry into its current form by laying out a genealogy of its antecedents across three distinct generations. These three generations of social forestry are roughly aligned with the overall political changes that have taken place in Indonesia, each of which engaged in their own mechanisms for defining and administering social forestry. The first generation roughly follows the period of New Order rule; a second generation began as the regime unraveled, resulting in a period of reform and restructuring of the political system. At this time, new legal frameworks were introduced, followed by the development of new implementation mechanisms. We argue that social forestry has entered a third distinct period that is characterized by the expanding interests of numerous stakeholders to formalize permitting schemes. This third generation presents new possibilities for redefining land management on Indonesia's vast national forests. The contributions to this special issue shed new light on the overall implications of these changes. We divide the findings across submissions, covering broad topical engagement on the economies, ecologies, and politics at different governing scales. From these findings we suggest a course for future research, and identify key policy challenges for the future of social forestry and for Indonesia.
\end{abstract}

Keywords: community forestry; CBNRM; Indonesia; genealogy of social forestry; political forest

\section{Impetus for the special section}

In Indonesia's presidential debate of 2019 - as was true five years ago - social forestry (SF) emerged as a prominent political commitment to improve access of rural people to land, creating opportunities for economic development while protecting its fragile remaining forests. SF in Indonesia has occupied much attention in Indonesia's policy circles, which are translating into everyday implementation practices in various ways. As of November 12th, 2018, the Ministry of Environment and Forestry (MOEF, henceforth Forestry Ministry) ${ }^{1}$ had issued 5,097 SF permits, or $2,173,063$ ha, an area that has more than doubled since 2014. A total of 497,925 households are involved in social forestry programs (See Galudra 2019). State programs to administer SF therefore create a unique scenario across a broad diversity of land management systems throughout the

\footnotetext{
${ }^{1}$ Due to the historical elements of this paper, we describe the current institution of the Ministry of Environment and Forestry as the Forestry Ministry to incorporate institutional functions under previous mandates as the Ministry of Forestry.
} 
Indonesian archipelago.

The purpose of this special section has been to take stock of evidence and to promote knowledge on the realities, achievements, challenges and pathways to sustainable strategies for the future. The impetus for this special issue however, is that there is only a handful of academic articles that have engaged with the overall breadth of the issues involving SF (these reviews are in part laid out in Anderson et al., 2015; Sahide et al., 2016; Fisher et al., 2018). Although accessibility to SF in broader international research databases is still lacking, this does not mean research is not taking place. There is considerable engagement and investment in learning about SF in Indonesia (Sahide et al., 2018a). Much of this engagement however, has been limited to platforms such as policy forums, WhatsApp chats, across popular media, and in grey literature. As a result, more and more stakeholders are actively engaged in influencing the shape of SF. Indeed, SF practitioners have expanded markedly in Indonesia and networks such as the Indonesian Communication Forum on Community Forestry (FKKM) continue to shape policy and practice. In this article, we describe the current moment of SF from numerous perspectives as part of a distinct third generation, one that requires critical reflection and more deliberate scrutiny. ${ }^{2}$ Furthermore, as SF is a growing policy phenomenon internationally, we believe it is time to try to take stock of processes unfolding in Indonesia, presenting empirical materials that could be spread more broadly across audiences in Southeast Asia and beyond.

In this introductory paper we contextualize SF in Indonesia, present findings from across the contributions of the special section, and provide overall guidance on future research. In order to do so, first, we present a four-part heuristic on the discursive drivers of SF. We believe this analysis provides a useful framework for situating the various overlapping, and often perplexing perspectives about SF. Second, we situate SF historically, differentiating three distinct generations as they have evolved in Indonesia. We argue that Indonesia has entered a third generation of SF because of the recent trend in the rapid expansion of permits, which has its own set of implications. Third, we present findings across the three common pillars of SF (Maryudi et al. 2012), which are i) livelihoods: the promise of economic development and an avenue for poverty alleviation, ii) rights of access, demanding acknowledgement from a history of dispossession and a re-consideration of who has rights to the forest, iii) conservation, particularly approaches to Community Based Natural Management (CBNRM), which has continued to reaffirm that empowering those closer to natural resources enables greater success in protecting natural resources and improving forest conditions (Zerner, 2000). Therefore, we have also aligned the paper contributions under these three broad headings, categorized as the politics, economies, and ecologies of SF's third generation in Indonesia. Fourth, we conclude by laying out a future research platform.

Although in the end we were able to generate a wide-ranging list of diverse contributions, two key challenges kept us from soliciting more submissions. The first is a result of national higher education and research reform policy in Indonesia to improve the quality of research. This has commonly become known as the scopus problem. Numerous people that we spoke to in conferences and at different universities, particularly graduate students conducting timely research, noted that they were required to submit to scopus-indexed journals. The second problem is that there is a great deal of knowledge among practitioners that do not have the time or experience to write in academic forms. Many NGOs that we spoke to often complain that they

\footnotetext{
${ }^{2}$ We recognize that in a review article by Anna Lawrence (2007; see also Gilmour, 2016), she has also described SF in terms of a first and second generation. In her review, she highlights a first generation that focuses on addressing tenure relations, whereas the second generation concern diversity, equity. She also proposes going beyond the second generation, promoting adaptation and learning. Our concept of three generations is distinct to the differentiation and political manifestations in the Indonesia context.
} 
are too busy doing the 'boots-on-the-ground' work or engaging in policy advocacy, lamenting that they did not have the time to reflect on their experiences. In one way, this resulted in a barrier for submissions, but it also created the opportunity for what we believe are timely innovations in Forest and Society's approaches to special sections. We have now piloted submissions for policy forums, notes from the field, and methodological engagement. This policy forum option presented unique and refreshing new perspectives about SF that might not have otherwise come into consideration among a more academic readership. Furthermore, we anticipate that these shorter and less theoretical pieces allow for a broader readership to connect with what we believe are timely SF policy discussions. Table 1 and Figure 1 show the geographic and topical breadth of the submissions. Across the many papers in this special section we highlight the comparative insights of SF programs and practices from different parts of Indonesia. Based on these analytical and comparative insights we draw implications for enhancing SF practice and research in Indonesia, setting out some pathways for continuing research going forward.

Table 1. List of articles in this issue

\begin{tabular}{|c|c|c|c|}
\hline Author & Title & Region / Scale & Category \\
\hline \multicolumn{4}{|c|}{ Research Article } \\
\hline Bong et al. & $\begin{array}{l}\text { What is success? Gaps and trade-offs in assessing } \\
\text { the performance of traditional social forestry } \\
\text { systems in Indonesia }\end{array}$ & Indonesia / National & General \\
\hline Pratama et al., & $\begin{array}{l}\text { Examining economies in forest: A case study of } \\
\text { silk value chain analysis in Wajo district }\end{array}$ & $\begin{array}{l}\text { Wajo (South Sulawesi ) } \\
\text { / District }\end{array}$ & Economies \\
\hline Suhel et al. & $\begin{array}{l}\text { Determinants of recreation demand in Kongar } \\
\text { Lake of South Sumatera: Approximate travel cost } \\
\text { method }\end{array}$ & $\begin{array}{l}\text { South Sumatra / } \\
\text { District (Unit } \\
\text { Management) }\end{array}$ & Economies \\
\hline Nuddin et al. & $\begin{array}{l}\text { Making the case for institutional support on } \\
\text { designing agroforestry technology models for } \\
\text { rehabilitating critical lands }\end{array}$ & $\begin{array}{l}\text { (South Sulawesi) / } \\
\text { District }\end{array}$ & $\begin{array}{l}\text { Economies / } \\
\text { Conservation }\end{array}$ \\
\hline Massiri et al. & $\begin{array}{l}\text { Institutional sustainability of community } \\
\text { conservation agreement in Lore Lindu National } \\
\text { Park }\end{array}$ & $\begin{array}{l}\text { Central Sulawesi } \\
\text { (National Park) / Unit } \\
\text { Management focused } \\
\text { on one Kabupaten }\end{array}$ & $\begin{array}{l}\text { Conservation / } \\
\text { Policy }\end{array}$ \\
\hline $\begin{array}{l}\text { Asmin, Darusman, } \\
\text { Ichwandi, Suharjito }\end{array}$ & $\begin{array}{l}\text { The policy of community-based forest } \\
\text { management in West Sumatra: Its arguments, } \\
\text { support, and implementation }\end{array}$ & $\begin{array}{l}\text { West Sumatra / } \\
\text { Provincial }\end{array}$ & Policy \\
\hline Tajuddin et al., & $\begin{array}{l}\text { Bridging Social Forestry and Forest Management } \\
\text { Unit : Juxtaposing policies imaginary and } \\
\text { practices, a case from Sulawesi, Indonesia }\end{array}$ & $\begin{array}{l}\text { Sulawesi Island / } \\
\text { Multiple Provinces }\end{array}$ & Policy \\
\hline $\begin{array}{l}\text { Wulandari and } \\
\text { Kurniasih }\end{array}$ & $\begin{array}{l}\text { Community preferences for facilitation program } \\
\text { in social forestry in Lampung, Indonesia }\end{array}$ & Lampung & $\begin{array}{l}\text { Policy } \\
\text { (facilitation) }\end{array}$ \\
\hline \multicolumn{4}{|c|}{ Policy Forum } \\
\hline Galudra & Capacity development on social forestry program & National & Policy \\
\hline
\end{tabular}


in Indonesia: Issues and challenges

(facilitation)

Suhardjito and Wulandari

A reflection of Social Forestry in 2019: Towards

Policy inclusive and collaborative government approaches

Fatem

Assessing the connectivity of social forestry to conservation policies in West Papua

Tanah Papua (West Policy Papua Province)

Cámara-Leret et al. The Manokwari Declaration: Challenges ahead in Tanah Papua

Policy / conserving $70 \%$ of Tanah Papua's forests

Conservation

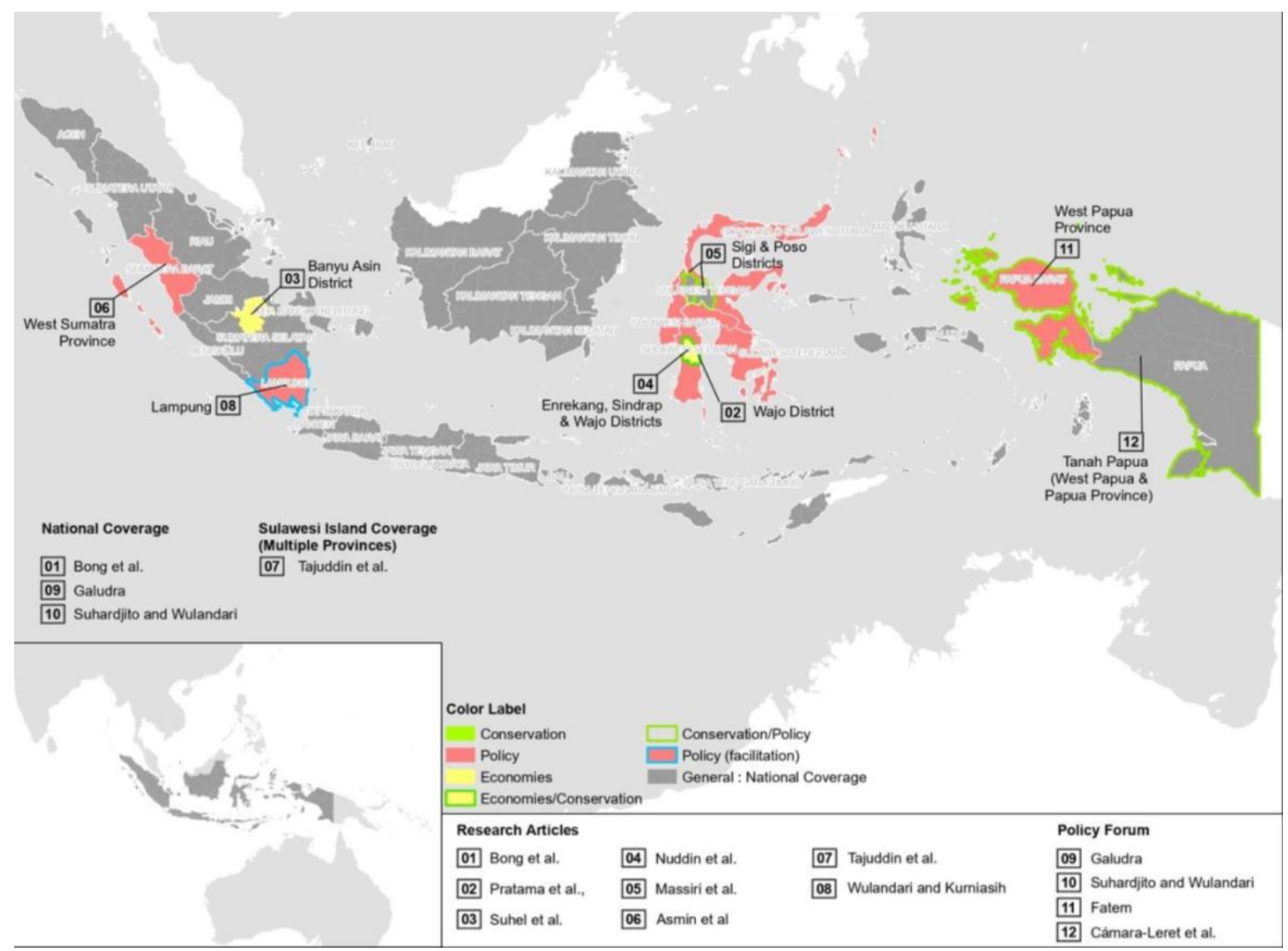

Figure 1. Spatial distribution of research articles and scale of analysis

\section{What is social forestry? A typology of SF streams of thought}

SF practice includes a diversity of perspectives, objectives, and goals. It is therefore often difficult to make sense of what people mean when they invoke, propose, and implement SF. In this section we turn our attention to reflecting on these varied perspectives, highlighting the ways that $\mathrm{SF}$ is understood and promoted. ${ }^{3}$ We seek to provide a broad categorization for the various ways

\footnotetext{
${ }^{3}$ The 40 year review by FAO offers a broad definition for SF (Gilmour, 2016). But more specifically, in the context of Indonesia, the Forestry Ministry also provides a terms that sets out a specific definition of the
} 
that SF proponents envision their programs, applications, and successes. Table 2 outlined the four broad categories that highlight the overall operational concepts and the actors that are likely to promote them.

Table 2. The Four "Discursive-Firsts:" Categorizing forms of mainstreaming and defining SF in Indonesia

\begin{tabular}{|c|c|c|}
\hline $\begin{array}{l}\text { Forms of Social } \\
\text { Forestry Discourse }\end{array}$ & Operational concept & Actors (or example of actors) \\
\hline $\begin{array}{l}\text { Community-first } \\
\text { perspective }\end{array}$ & $\begin{array}{l}\text { Premised on rights and participation in } \\
\text { decision making process }\end{array}$ & $\begin{array}{l}\text { (RECOFTC), peoples hold the keys (RECOFTC, } \\
\text { 2011). required strong participatory concepts and } \\
\text { efforts" Consequence: Ambiguity existence, due to } \\
\text { the diversity of community based traditional } \\
\text { application and capacity building. RECOFTC's work } \\
\text { is guided by the principles of clear and strong } \\
\text { rights, good governance, and fair benefits for } \\
\text { millions of forest-dependent people. Source: } \\
\text { Indigenous rights first (AMAN). Consequence: } \\
\text { struggling to meet state formal legal back up. }\end{array}$ \\
\hline
\end{tabular}

Legality-first (the formal) perspective
The formal perspective, which is embodied by the politico-jurisdictional roles in government. Legality first (government-state) based on the control, required formal scheme (consequence: overgeneralization). Communities have to fit in the restricted legal formal/schemes regulated by the government.

\section{Conservation-first perspective}

\section{Development-first} perspective
The conservation perspective usually consists of those that seek to protect against species extinction, biodiversity conservation, and increasingly under the terms of climate change.

What we are getting from the community access from the forests? What is the outcome for financial and economic both in the individual level.community level and regional development level
Forestry Ministry push and offer legal schemes to operationalize community forest based on the legaljurisprudence menus
Wallacea, BINGOs. These actors see the urgency of protecting the environment as they foremost objective of SF.
Private sectors asking for people and individual forest plantation.

Development Planning Ministries and economic ministries required livelihood and economic perspectives outcome from the forests

However, by no means are the discursive categories outlined above rigidly defined, and increasingly the notions that shape the various understandings of SF are fluid and involve inherent contradictions. We often find stakeholders promoting one discursive aspect of SF in one setting, while promoting its other discursive interests in another. For example, the community-first perspective arose as part of research and policy initiatives to support community-based natural resource management, a long tradition related to the study of common property resources and 
the rules that shape negotiations related to resource management. Indonesia in particular, has seen a particular emphasis on supporting the rights of indigenous people.

We believe that further research in this area, understanding the discursive and political implications of SF contestations, is necessary, particularly to better understand the imaginaries about SF and how such visions structure its outcomes. For now, we offer the discursive categories to help readers to sift through and better understand what various actors may be advocating when they are involved in SF research, policy, or implementation. In the subsequent section, we seek to bring the reader up to date on these discursive differences by taking a longer view of the current moment of SF. To do this, we divide SF into distinct periods across three 'generations.' These historical factors are important as a segue to understanding the current politics, economies, and ecologies discussed in this special section.

\section{The genealogy of social forestry in Indonesia: Arriving at the third generation}

In this section we take a step back to contextualize the historical developments that brought SF into its current form in Indonesia. We present a genealogy of its antecedents across three generations that are roughly aligned with the overall political changes that have taken place in Indonesia, each of which engaged in their own mechanisms for defining and administering SF.

\subsection{The first generation--The 1970s-1980s}

What we call the first generation of SF in Indonesia is driven by the power of the New Order era, with its strong and centralized governance approach. During this period, state policy created a land tenure and forestry regime that provided the Forestry Ministry with the authority to directly control Indonesia's forest areas while systematically overlooking traditional or customary rights and practices in forest management (McCarthy, 2000; Safitri, 2015). This centralized role of the state employed much coercion and conducted limited, pro forma consultations, identifying and classifying forests and land (political land-use zones) largely based on scientific, bureaucratic and institutional practices of forestry without considering the social and economic needs and practices of local, forest-margin communities (Vandergeest and Peluso, 2015).

The State, particularly the Forestry Ministry was the most powerful actor during this era, controlling forest policy and management, while systematically weakening traditional forest practices (Barr et al., 2006). During this period, the centralized and bureaucratic forestry regime excluded large populations of forest communities that had practiced traditional land management systems on these lands for generations. Many communities across Indonesia discovered that their ancestral lands had been designated as national forest lands and subsumed within the forest estate. Nevertheless, a number of community groups, especially those that could maintain formal connections with the State, were able to maintain control over their forest. One example is the Ammatoa Kajang community in South Sulawesi, which has become prominent in recent years for gaining formal recognition as an indigenous (adat) community (Fisher, 2019).

The first generation of SF in Indonesia began alongside much of the global interests in CBNRM, which became a central topic in international forums, and thus shaping support mechanisms of bilateral and donor projects. It emerged out of the recognition that communities had an important place in the forest (Zerner, 2000). In the 1970s, around the world, collective, community-based movements emerged that sought to push back against coercive and exclusionary forest management practices. Advocates protested against conservation measures that excluded local communities, and ignored their rights to land, citing the harmful effects to local social and material wellbeing (Dressler et al., 2010). The new movement drew on notions of participatory engagement, recognition of indigenous knowledge and community needs. The 8th World Forestry Congress, hosted in Indonesia in 1978, resulted in the "Jakarta Declaration," which reflected a turning point toward greater understanding of forestry's contributions to social and 
economic development, particularly the benefits and wellbeing of rural people. Momentum from the Congress, and from the Jakarta Declaration, compelled the New Order government to showcase examples of how they were also working to support SF, especially in Java. However, while these processes planted the seeds for SF programming to grow, this first generation was characterized by limited SF engagement, primarily in the form of micro, project-level initiatives (Colfer and Resosudarmo, 2002). In general, the centralized character of authoritarian forest management by the New Order trumped any opportunity to engage in systematic programming support for SF (Lindayati, 2002).

\subsection{The second generation--The mid-1990s-2012}

The second generation of SF emerged following Lucas and Warren (2013). As the state unraveled, and was reconstituted in the form of democratic decentralization, national discussions sought to determine how best to administer the vast land area of state forests. Civil society organizations (CSOs) concerned with community land rights and access to forest resources, argued against the Basic Forestry Law (BFL) 5/1967, demanding that they be removed from state forests (Lucas and Warren, 2013). Many CSOs suggested that the broader legal framework for forest management should return to the Basic Agrarian Law (BAL) 5/1960, which provides more explicit rights and opportunities for rural communities. Failing to achieve fundamental changes to land law (consolidating the BFL and $\mathrm{BAL}$ ), several outspoken CSOs negotiated for a redrafting of the BFL passed as Forestry Law No. 41/1999. These CSOs succeeded in incorporating requirements for more deliberate participation of communities. SF therefore became a uniquely positioned and strategic approach to deliver more participatory mechanisms for involving local communities. ${ }^{4}$ As described in Table 2 above, the notion of SF as an idea also fulfilled multiple interests in what might be possible by its application. Nevertheless, applications during this second generation remained vague and contested for the lack of implementing regulations, which were contingent upon the precedent shaped by project implementation with external support.

This second generation was especially influenced by the advocacy and close involvement of FKKM (Social Forestry Communication Forum). FKKM, a network of civil society organizations and academics, came together with a concerted voice to demand reforms in the BFL. Due to the mandates for community participation in the Forestry Law, FKKM also began to take on more formal advisory roles within official state positions in the Forestry Ministry, as experts that could help translate and define adequate participation. Donor organizations, also increasingly supportive of SF implementation, also began to assert more direct influence in guiding SF projects. Therefore, by taking advantage of weakened state power, during the transition of power from the New Order period into the Reformasi era, strong pressure from CSOs resulted in acceptance of a broader guiding framework of community participation applied through SF policies adopted by the government.

The inclusion of articles on community empowerment and participation in the 1999 Forestry Law reflected a unique achievement of CSOs in Indonesia. Using the opportunity from the new Forestry Law, community forestry $(\mathrm{HKM})$ schemes were piloted as the first systematic mechanisms across Indonesia. The Forestry Ministry began working with international organizations to develop

\footnotetext{
${ }^{4}$ Article $3 \mathrm{~d}$ and $3 \mathrm{e}$, for example states that "Forestry programming are intended for the maximum benefit and sustainable prosperity of the people by means of: (d) promoting capabilities and developing the capacity and potential of the community in terms of participation, justice and environment-oriented concepts so that the social and economic sustainability, and resilience against the impacts of external changes that may be created; and (e) guaranteeing the distribution of just and sustainable benefits."
} 
various $\mathrm{HKm}$ schemes as ad hoc projects. HKm projects included designated funding, field activities, and the creation of farmer groups and forums; however, they offered little in the way of formal legal recognition or management authority. Therefore, although HKm projects at that time supported improved planting activities and the promise of enhanced incomes, they did not address the broader challenge of devolved decision making over land management responsibility governing these lands. Formal institutions welcomed these projects because they were supported by outside funds, but they still faced the regulatory inconsistencies of not having rights to the forest.

Although regulatory reforms were taking place, bolstered by generous external support to implement SF projects guided under the principles of greater local participation, progress in affecting change on a larger scale during this second generation was still limited. In the early 2000s, Lampung Province began to push the boundaries of HKm implementation, leading the way for more systematic approach, presenting a framework for transforming projects to more deliberate regulatory approaches that began acknowledging local community rights. The recognition took place not as land rights, but in the legitimacy of establishing forest farmer groups closely related to the regional coffee industry, due to their role in the supply chain. Separately, in Java, the State Forest Corporation (SFC, or Perum Perhutani) began to allow communities comanagement arrangements through what they described as a "Joint Community Forest Management (PHBM)" scheme. However, evaluations (Maryudi, 2011) pointed out the lack of equity in the benefit-sharing arrangements of these programs, which communities described as more tokenistic and procedural, without the material benefit sharing outcomes. Overall, these exemplary cases from Sumatra and Java show that although SF as a concept was gaining acceptance as an idea within formal institutions, it was still limited to a project basis, and unable to 'penetrate' applications into a meaningful area of land within state forests. During the second generation, a vocal set of State actors were especially against the incorporation of SF on the vast conservation forest lands, arguing that the presence of people in these areas run counter to the aims of conservation.

Amidst these overall conditions of the second generation however, calls for more fundamental land rights gained further momentum as part of transnational movements based on custom or indigeneity. Proposals for designating customary forests (hutan adat), increasingly gained currency as part of the global discourse on indigenous community land rights. Such efforts sought to explicitly reorient authority for land management to considerations for local customary practices. At the same time, in concert with a series of other rural development reforms, the government suggested the adoption of the "village forest scheme" (hutan desa), structurally embedded under the village government. The application for an adat forest therefore was to be subsumed within the broader village authority as part of local customary practices. This was of course problematic in many instances, as adat leadership structures do not necessarily overlap with village governing authority.

In sum, the second generation had transitioned away from the centralized model, indicative of opportunities to be actively involved in redrafting the Forestry Law, and therein incorporating explicit mandates for participation. As a result, projects began to emerge as a way to guide regulatory processes, provide a foundation for applying SF schemes. This included community forests (HKm in Lampung, and elsewhere), PHBM in SFC areas of Java, new ideas for village forest schemes, and the beginnings of adat forests that would emerge as a key area of contestation. However, although the broader regulatory umbrella had changed and initiatives were becoming more widely accepted - particularly those that came with external budget support for projects the total area devoted to SF remained limited, and applications still only partially recognized. This would change in what we describe as the transition into the third generation.

\subsection{The third generation--2012-present}


The third generation of SF experienced rapid expansion as part of popular support for implementing large-scale government programming for rural community access to land. Formalizing rights as part of government programs presented new land management possibilities for communities in Indonesia's vast national forests (see Asmin et al., 2019; Bong et al., 2019; Fatem, 2019; Wulandari and Kurniasih, 2019 all part of this special section).

The third generation was strongly influenced in the presidential campaigns leading up to the eventual election of Joko Widodo (2014), particularly through the increasing role of AMAN and their advocacy for indigenous land rights. The Constitutional Court Decision (35/2012) supporting plaintiffs rights in state forests was a landmark decision that determined that state enclosures of indigenous peoples lands were unconstitutional (Myers et al., 2017). This led to a renewed focus on legitimizing indigenous land claims, seeking to effectively remove them from state forests. Meanwhile, alongside other prominent CSOs, AMAN joined forces with the Jokowi campaign, supporting its populist messaging. Upon Widodo's election, AMAN gained influence by occupying positions through presidential advisory posts and their influence in guiding policy directives (Sahide et al., 2016). Outwardly, they lobbied President Widodo to fulfill his commitments to advance the rights of adat communities. To date there are 28,286 ha of indigenous lands that have been recognized in state forests involving 16 indigenous communities.

Before the Jokowi administration, less than 1 million hectares was under SF designation. Jokowi set out to implement an ambitious goals for rural development, including promises to expand communities' access to land under SF to an area covering up to 12.7 Million hectares. In his first term, the area under SF programs has more than doubled, to over 2 million hectares, and this has been accompanied by the development of new SF schemes, including community plantation forests, new partnership mechanisms, such SF concessions (IPHPS) within SFC ${ }^{5}$ and in conservation areas. Ministerial Regulation (P.83/2016 on Social Forestry) placed SF under a single regulatory umbrella, clearly outlining the specific legal definitions of $S F$, the various types of schemes, and the process for gaining formal management rights. However, as we will discuss in further detail below, the rapid expansion of SF permits have overwhelmingly focused on issuing permits with limited attention to the implementation of SF programs.

In sum, the third generation of SF gained legitimacy and momentum from the Jokowi election. However, as noted above, reforms that had taken place prior to his election were not insignificant. In particular, the growing effort for recognition of indigenous rights created a forceful new contestation over state forest lands. AMAN's growing political influence also established an agenda beyond indigenous rights that was steeped in the rhetoric of SF and agrarian reform. Although the Widodo administration supported a significant expansion of areas under SF schemes, one of the major critiques of SF through this third generation has been the emphasis on streamlining the permitting process while overlooking the broader intent and interests of SF. In the remainder of this paper, we turn to the contributions that further contextualize this third generation.

\section{What's Inside?}

This special section includes eight research articles and four shorter policy pieces. Table 1 and Map 1 highlight the authors and titles, locating each contribution geographically. Some of the articles are national in scope, while others detail specific findings at a community level. Following the broader policy imperative of SF, we divide the contributions into three distinct categories. We first highlight economies, then turn to conservation, and finally we situate the papers that address

\footnotetext{
${ }^{5}$ with benefit sharing arrangement (70-80\%: 20-30\%)
} 
specific policy issues.

Before turning to these three broad categorizations however, our first contribution by Bong et al. (2019) sets out to highlight an important distinction in the types of SF that often result in a point of confusion in our broader understanding of SF. They define SF as the management of forests by local communities to achieve various environmental, social and development goals, including climate change mitigation and adaptation, food security, nutrition and livelihood support (Fisher, 1995; Taylor, 2000; Wiersum, 2004).

Bong et al. introduces different types of SF that opens the possibilities for a mixture between the traditional and the formal. This represents an opportunity to expand the broader notion of the state-led mandate that has been the focus of recent years. Traditional SF refers to forest management that has long been practiced locally by a community, differentiated from the formal SF schemes implemented and governed by the State. The key distinction they make is the differentiation in terms of the objectives in the way the forest is managed. Formal SF is introduced by outside parties and requires an official permit, such as a written management plan that includes a set of defined objectives. As such, expected outcomes are more geared toward fulfilling state mandates rather than inherent community interests. Meanwhile, traditional SF is also regulated through local or customary institutions, in which the governance of forest uses is often adaptive to, and evolving with various livelihood, environmental, and political dynamics both within and outside the community (Wiersum, 1997). Nevertheless, formal and traditional SF are never purely one way or the other, and often sit on a sliding scale that incorporate the involvement of the State, and the interpretations of local actors.

\subsection{The economies}

The economic impacts on livelihoods and economies remains a contested outcome of SF. Is SF good for local economies, and how does engagement in SF support new livelihood opportunities? Alternatively, does SF necessarily benefit local economies or are there winners and losers in the process?

The three papers that we highlight in the economies section, address three very different ways of thinking about SF-related economics and livelihoods. The first is a straightforward value chain analysis, an extremely effective way of examining how communities are dependent on particular commodities. This approach also shows which actors benefit, when interventions are introduced as part of particular programming. The case study presented by Pratama et al. (2019) on the silk industry of Wajo highlights the realities experienced among silk producers, noting that their benefit-sharing arrangements with middlemen remain equitable. However, such benefitsharing, although presented as a success story, is by no means automatic. Past issues from Forest and Society have shown the insidious control that middlemen can enact upon forest farmers, undermining their bargaining positions by using cultural terms of debt bondage, for example in the clove industry in Maluku (Salampessy, 2017). Indeed, the Salampessy case shows how debts assigned to individual trees only further entrench these unequitable relations through SF designation, a fact that formal SF designation would find difficult to identify and address.

The second paper in the economies section takes a very different approach to valuing economies. Rather than examining the particular earnings of a given commodity, Suhel et al. (2019) use a payment for ecosystem services approach to estimating the potential economic benefits from recreation at Kongar Lake. The analysis looks at tourism potential in Kongar Lake more broadly, as a way of making the case for protecting natural resources as recreation destinations in South Sumatra (Suhel et al., 2019). The analysis also focuses much more on the consumer side, highlighting the various factors that visitors consider as determinants for their continued recreation at these sites. Such approaches to economic valuation governing natural resources, help make the case for local economies premised on the consumption of natural 
resources, such as panoramic views, rather than a resource to be exploited. This argument indeed helps expand the notion about the broader implications of a distinctly social forestry.

\subsubsection{The promise and paradox of agroforestry}

The third paper that we highlight on the economies section highlights a common overlap in the perception of SF, namely around the nature of activities among forest farmers. This terminology often falls under the broad category of agroforestry, referring to the cultivation of multiple crops at a single site, or as part of a shifting cultivation system. Similar to the discourse of $\mathrm{SF}$, agroforestry promises both ecological and economic benefits. Following from an earlier publication in Forest and Society about Thailand (Tongkaemkaew et al. 2018), Nuddin et al. (2019) extends the analysis around the benefits and possibilities of agroforestry. They highlight a case from the Sulawesi uplands, showing that agroforestry far outweighs the benefits of monocropping systems. They begin by describing the potential that mix-cropping systems can have in improving upper watersheds, restoring critical lands, supporting water retention, slowing soil erosion, and maintaining nutrients. The ecological benefits are further extended by the reduced dependency on chemical inputs that also help protect rivers and water quality by reducing exposure to toxic materials.

Central to their analysis, Nuddin et al. quantitatively show that economic benefits in agroforestry far exceed those in monoculture systems through a simple expenditure analysis relative to earning potential. They emphasize that agroforestry is not only more sustainable ecologically, but also more viable economically. Beyond the economic benefits, Nuddin et al. also showcase the safety nets that agroforestry systems provide, namely resilience against the low prices and crop failures common to monocropping systems. Furthermore, mixed cropping systems also provide greater opportunities to harvest food, collect medicine, and generate continuous income as part of sequenced harvests from selected crops.

Although Nuddin et al. contend that the benefits of agroforestry are well understood and widely recognized, in the second part of their analysis they conclude that repurposing upper watershed areas into agroforestry systems will not succeed without meaningful commitment and support from formal institutions, and suggest some ways to engage those institutions. This latter aspect raises an important point about the overall SF policy that we believe requires further examination: Why are formal policies and institutions not more supportive of agroforestry systems? What are the obstacles standing in the way of the approaches described by Nuddin et al. that can lead to be more ecologically- and economically-friendly land use systems?

Scaling back to the national level, Galudra (2019) discusses claims about the overall economic achievements of SF in Indonesia. This includes the contribution of SF towards reducing Indonesia's gini ratio (from 0.41 to 0.39 ), indicating a reduction in economic inequality. Furthermore, Galudra also praises government efforts in facilitating the establishment of 2,647 SF business permits across Indonesia. Of course, there are difficulties in attributing these figures and conclusions solely to SF. Not only are better methodologies and more comprehensive studies required to understand the economic impacts of SF, closer scrutiny should also be given to the broader agrarian questions of who benefits more broadly, and who benefits across individuals and groups (Sikor and Lund, 2009). This latter point is critical, especially as SF is assumed to provide economic development opportunities for the poor, particularly those vulnerable from lacking access to land. Schreckenberg and McDermott (2009) highlight the importance of identifying the squeeze among the most vulnerable. Indeed their analysis shows that the most vulnerable tend to be left behind in program implementation. Further inquiry on this topic should highlight what types of economies are being supported and facilitated (both formally and informally), who is gain accessing, and who is being excluded. 


\subsection{The ecologies}

Due to the overwhelming focus on the social aspects of SF, particularly those related to livelihoods and rights, complaints often emerge among those who ask, Where is the conservation? The conservationist viewpoint also tends to believe that there has already been significant encroachment on forests. Therefore, by expanding a program that provides expanded access, forests will only be further destroyed. Conservation advocates often point to comparisons of protected areas where forest rangers ensure the protection of forests through regular patrols, in comparison to forests that have not had sufficient enforcement, particularly at sites that have been devolved to district level management. This view suggests that the guardians of the forest are responsible for keeping communities out of the forest, and they believe that once claims begin to expand, there will be no end to stopping it.

From a policy standpoint, conservation areas have been considered the last frontier, in the past completely off limits to SF. After a long contested battle however, the conservation bureaucracy has opened up the opportunity to include SF within these protected areas. However, there are several fundamental aspects that are still specific to the issue of conservation areas. The indicators for conservation partnership schemes, for example, include durations that last only five years, and issues related to timber harvesting in conservation are still unresolved. One of the contributions in this special issue addresses these considerations. In Lore Lindu National Park, Massiri et al. (2019) examine a community conservation agreement from the standpoint of sustainable forest management. They look at how access provided to local communities determines outcomes on conservation by not only examining the institutional arrangements for protecting national resources, but also incorporating indicators about conservation achievements. We believe that this type of research is critical in addressing the perceptions about people in forests, and merging interests between community access and conservation. Much of the discussion related to conservation often involves considerations for watersheds. As noted above, Nuddin et al. (2019) approach the rehabilitation of critical lands through agroforestry programming.

\subsection{Policy (and politics)}

The issues listed in the economies and ecologies sections discuss SF policies in several overlapping areas. The section on policy, highlights a series of key issues. The first involves a comparison of the overlap between the establishment of Forest Management Units (FMUs) as a critical aspect in the expansion and designation of SF programs (Tajuddin et al., 2019). The second shifts the discussion to a key policy shortcoming that is increasingly identified with the frustration inherent in the rapid pace of "printing" SF permits: "Who is responsible for supporting the facilitation and implementation of successful SF?" Contributions by Galudra, 2019; Wulandari and Kurniasih, 2019; and by Tajuddin et al., 2019, offer important perspectives on these institutional issues. Third, recent years has also seen the emergence of specific policies related to adat in Tanah Papua, specifically around the question of who gets to decide how policy will unfold in Papuan forests (Cámara-Leret et al., 2019; Fatem, 2019). Finally, Bong (2019) also addresses the overall implications of formalization. Indeed the mechanisms for SF in Indonesia have required new bureaucratic processes only accessible to those who have connections to formal institutions. In many ways, local knowledge of forest management is rarely transferable into the necessary paperwork, and in the worst of cases can even undermine the informal institutions that have been critical to effective resource management.

\subsubsection{Intermediaries of SF: Facilitators and extension agents}

Galudra (2019) and Wulandari and Kurniasih (2019) points to the challenges of coordinating 
between central and provincial governments, relationships with local communities, and involvement of private companies and NGOs. Galudra specifically shows that SF programs suffer from poor coordination, not just across institutions, but also within the Forestry Ministry. Most obvious is the links between the Directorate General of Social Forestry (responsible for administering permits), its relationship with the Center for Forest Extension (overseeing staff persons working with local communities in social forestry projects), and the Directorate of Environmental Partnership (which also has a pivotal role in facilitating various stakeholders). Galudra's contribution focuses on the limited provision for training forestry extension agents who are responsible for the technical aspects of working with local communities. Galudra also argues that this is a missed opportunity, since focus on issuing permits has overlooked the role of those who can help communities maximize the income they obtain from the species that they grow in community forests, connect them with new potential markets, and support improved land management for conservation. Galudra concludes by suggesting that these issues must be addressed through institutional reform, specifically through developing technical modules on SF training and enhancing the number of and capabilities of facilitators and extension agents. Meanwhile, Wulandari and Kurniasih provide a more detailed examination of the type of facilitation that local communities require, and the type of support that interests them at different stages of management activities. They especially highlight the important role of focusing facilitation on livelihoods (what they describe as entrepreneurial aspects), and also point to more democratic opportunities to access trainings from across farmer groups. Meanwhile, the role of capacity building, they suggest, is not only limited to the target communities themselves, but that other institutions also require a more targeted focus on training and facilitation.

\subsubsection{The emergence of Tanah Papua in Indonesian SF policy}

The contributions concerning the two provinces of Tanah Papua, by Fatem (2019) and Cámara-Leret et al. (2019) point to some significant and timely issues related to forest conservation. Both articles discuss the broader changes affecting the region, particularly those related to the policy dimensions of ensuring conservation in one of the world's most significant area of biodiversity. They are especially focused on the question of who gets to decide over governing this region faced with rapid and significant change. Fatem (2019) argues that while the shift in Indonesia's forest policy is moving towards SF, he raises the timely question of how such applications will benefit indigenous communities in Tanah Papua. The reluctance of the central government to devolve resource management to the local level is indicative of the land area designated to SF in Tanah Papua. This is not unique to Indonesia, as studies in other countries have also found that many governments are reluctant to devolve natural resource management decision making to communities, especially when it involves significant material and immaterial values (Sikor, He \& Lestrelin, 2017; Ribot, Treue \& Lund, 2010). In Tanah Papua, Fatem explains, this political barrier is exacerbated by the insufficient policy makers' understanding of the problems on the ground and the lack of collaborative effort of multidisciplinary teams in addressing these problems. Meanwhile, Cámara-Leret et al.'s (2019) discusses a multi-stakeholder policy declaration that provides guidance on future priorities for Tanah Papua.

\subsubsection{The implications of formalizing SF}

Bong et al. (2019) highlight the trade-offs that traditional SF faces in adopting formal SF schemes prescribed by the central government. While formal SF schemes may help traditional communities gain relative security over tenure, they must accept it at the expense of their social institutions. That is, formulation of policies to devolve forest management through formal schemes often neglects the varied character of local institutions, resulting in homogenous and rigid policy instruments that undermine these existing arrangements (Fisher et al., 2018; Kamoto 
et al., 2013; Moeliono et al., 2017). The relative tenure security in formal SF schemes can also be problematic as it might result in the exclusion of some groups within a community. As the state imposes control over forests, the rights to forests are granted to groups or communities as regulated within the respective schemes. They are often limited to use rights, and are frequently time-bound.

\section{Future SF Research}

Although the submissions from the special section have provided great depth to our understanding about the current moment of SF in Indonesia, they also point to some key blinders and areas to pursue for future research. Many of the contributions engage on several different themes, and we have found it useful to divide our analysis across three broad pillars of SF economies, ecologies, and politics. We thus highlight future research priorities within these three aspects. However, by no means are these categories fixed, and indeed require fluid boundaries.

\subsection{Economic Futures}

In this issue, Suhel et al. have focused on economic valuation of a resource and its relationship to the broader economic development opportunities from eco-tourism. Most of the research related to economic issues, however, discusses the importance of value chains and the need for improved understanding about commodity benefit-sharing for farmers involved in SF (Pratama et al. 2019; Nuddin et al. 2019). Similarly, Salampessy et al. (2017) explored the ways that farmers can lose access as part of the changing means of production. Enhanced understanding of the vulnerabilities present with changing land access is a longstanding theme in SF (McDermott and Schreckenberg, 2009; Fisher et al., 2018).

Although not represented in the contributions in this special issue, we have also begun to identify other ways of examining the economic aspects of SF. On the one hand, students in forestry programs in Indonesian universities are increasingly interested in the economic aspects of cooperatives, farmer groups, village enterprises (BUMDes) and analysis of the overall financial aspects of diversification and further cultivation of forestry products. However, such research has not been made accessible to wider policy forums, and furthermore, has not been aggregated into larger economic studies. Galudra makes reference to improved Gini Coefficient as signalling the arrival of SF reforms, but such figures require greater scrutiny to contextualize their findings at different scales, ones which point to developing a greater understanding of the benefit/burdensharing arrangements, and which devote specific attention to the overall winners and losers from SF initiatives.

Furthermore, government supported accountability mechanisms are now being used to to better understand the economic impacts of SF. For example, a series of government-supported studies have taken place at the national (Supriyanto et al., 2018) and provincial levels (e.g., Sahide et al., 2018b specific to South Sulawesi). Sahide et al.'s study examines the economic benefits from SF by incorporating economic indicators directly related to revenue associated with forest industries. Given that SF is still new, however, they discuss the challenges of identifying direct and immediate financial returns, and thus expand the scope of analysis to incorporate approaches for identifying indirect economic benefits.

Given these broad research trends on the economic elements of SF, we see great potential to bring greater depth to the issues highlighted above, such as those related to: environmental valuation (i.e., PES), value chain analysis, institutional arrangements, and the overall power elements that determine who benefits from changing economies. Additional studies are required that range from the critical to the pragmatic, ones that highlight unintended consequences, and those that help pinpoint initiatives that can support livelihoods and improve government accountability mechanisms. 


\subsection{Ecological Futures}

One of the areas that Bong et al. (2019) identified as a central gap in understanding SF in Indonesia is the lack of discussion on forest conditions and how this affects local forest management, particularly the ways in which a SF system adapts to changing forest conditions. Their analysis shows that less than $20 \%$ of the cases studied examines the biophysical conditions of the forest (biological diversity, tree characteristics, elevation/rainfall/climate, soil characteristics/fertility, or forest size). Indeed, this true not only for the contributions reflected in this special issue; conservation has received little attention within the designated programs being supported in the expansion of SF permit schemes.

We also highlight the important work by Massiri et al. (2019) that focuses specifically on community conservation agreements, partnerships that involve communities in forest conservation efforts. But as noted above, these types of schemes are still conducted on a trial basis, with few cases to reflect on, indicative of the ongoing distrust between the conservation wing of the Forestry Ministry in relinquishing enforcement efforts. Given that there is still a strong voice in favor of removing and restraining access of people to forests, timely research would help shed light on the following questions: What type/s of SF has positive or negative impacts on conservation? How are new ways of administering SF continuing to affect ecological outcomes? What role can research play in helping to better understand these conditions and support unfolding dynamics?

Forest and Society has also prepared a special issue specific to this topic on community-based conservation initiatives in the Eastern part of Indonesia. The premise of this engagement is that amidst all the critiques of State-based and community-based conservation schemes, conservation still happens. Why is this so, and how do communities go about it? What type of longstanding practices and emerging initiatives help to ensure that this occurs.

We are also becoming aware of an increasingly vocal movement towards ethnobotanical studies, in which communities are taking increasing initiative and authority in their own traditional and historical ecological knowledge by cataloguing their own plants and taxonomic systems. We believe this presents a rich area for future research, and that it can provide a counterweight to outsider perspectives about conservation.

\subsection{Policy Futures}

With the rapid proliferation of areas under SF designations, as well as the ever-increasing types of SF schemes being designated, there is much research that needs to be done to follow up and help explain just how these trends are unfolding. As SF receives a greater profile amidst populist policy positions, research needs to remain focused on the terms of these designations. Indeed, Lund (2016; see also Fisher et al., 2018) has described this as 'reciprocal recognition', in which the policy initiatives seek to formalize community SF arrangements. But this does not necessarily mean that the communities themselves recognize government authority for doing so. Indeed, formalization can sometimes mean access lost rather than access gained, particularly when communities are not viewed as monolithic, but as networks of actors and interests (Agrawal and Gibson, 1999). 'Social forestry' therefore constitutes a 'contract'. It links property and citizenship to political authority in society. Therefore, the exchange for receiving recognized property rights over the forest and its lands means that local communities at the same time recognize the political power and authority of the state (see Lund, 2016).

Research should continue to probe and scrutinize the changing power relations with respect to SF policy, seeking to answer the classic agrarian questions around who benefits from such arrangements, and who loses (Sikor, 2006; Bernstein et al., 2018). Indeed, the very selection of terms like SF versus community forestry (or CBNRM), present a historical blueprint in which tracking its genealogies could help to understand the implications of why SF policy has taken the 
form that it has today. Is the process of SF recognition as it has been put in place today connected to the notions of permitting and licensing land arrangements that are common in land negotiations in Indonesia? Do such arrangements weaken particular stakeholders in the process, namely those who do not have access to formal channels? No doubt examples from elsewhere highlight that bureaucratic mechanisms for formalization, and the overemphasis on issuing SF permits can lead to negative effects that undermine the very institutions they were intended to recognize and empower. Can research help to support the development of principles and frameworks that guide future formal SF manifestations? If so, in what ways, and through what indicators and safeguards? Without more rigorous scrutiny of SF and its effects, the overemphasis on promoting bureaucratic forms of recognition could put SF at risk of becoming another dirty word derived from another lofty policy promise.

On this note, the role of research in policy is also increasingly being discussed in terms of coproduction of knowledge (Beier et al., 2017). Although the notion of co-production has gained popularity, we should also be cautious about the practical outcomes that result from scientific research. SF as a policy ideal contains a great deal of ambiguity in the goals that it purports to pursue. Therefore, the co-production elements of SF are necessarily tricky, and vulnerable to the interpretations and whims of administrators or local elites, at risk of being manipulated by vested interests. Acknowledging these interests and understanding the implications of engaging in coproduction is an important area for future research. This research might also connect with some of the rigor demanded by Galudra (2019), that more deliberate focus on capacity building programs for facilitators and extension agents, could help ensure greater accountability.

We close this discussion by scaling out, highlighting the value of this research in Indonesia, in terms of the breadth and expanse of SF taking place across this vast and diverse archipelago. Although we have highlighted the particularities of SF in Indonesia through its genealogies and various framings, the popularity of SF is also expanding and being applied elsewhere. Moeliono et al. (2017) has conducted a comparative study of SF in Vietnam and Indonesia, and Forest and Society is also preparing a special section on community forestry in Vietnam. Other countries throughout Southeast Asia and beyond are also experimenting with SF policies with the same interests of empowering communities, improving livelihoods, and supporting conservation outcomes (Maryudi et al., 2012; Gilmour, 2016). Indeed, these emergent issues in Indonesia have much to offer beyond its borders - theoretically, methodologically, and practically.

\section{References}

Agrawal, A., \& Gibson, C. C. (1999). Enchantment and disenchantment: the role of community in natural resource conservation. World development, 27(4), 629-649.

Anderson, J., Mehta, S., Epelu, E., \& Cohen, B. (2015). Managing leftovers: Does community forestry increase secure and equitable access to valuable resources for the rural poor?. Forest Policy and Economics, 58, 47-55. https://doi.org/10.1016/j.forpol.2014.12.004

Barr, C. M., Resosudarmo, I. A. P., Dermawan, A., McCarthy, J., Moeliono, M., \& Setiono, B. (Eds.). (2006). Decentralization of Forest Administration in Indonesia: Implications for Forest Sustainability, Economic Development, and Community Livelihoods. CIFOR.

Bernstein, Henry, Harriet Friedmann, Jan Douwe van der Ploeg, Teodor Shanin, and Ben White. (2018). "Fifty Years of Debate on Peasantries, 1966-2016." The Journal of Peasant Studies 45, no. 4: 689-714.

Bong, I., Moeliono, M., Wong, G., \& Brockhaus, M. (2019). What is success? Gaps and trade-offs in assessing the performance of traditional social forestry systems in Indonesia. Forest and Society, 3(1), 1-21. doi:http://dx.doi.org/10.24259/fs.v3i1.5184

Beier, Paul, Lara J Hansen, Lynn Helbrecht, and David Behar. (2017). A How-to Guide for 
Coproduction of Actionable Science. Conservation Letters, 10 (3), 288-96.

Bong, I. W., Moeliono, M., Wong, G. Y., \& Brockhaus, M. (2019). What is success? Gaps and tradeoffs in assessing the performance of traditional social forestry systems in Indonesia. Forest and Society, 3(1), 1-21. http://dx.doi.org/10.24259/fs.v3i1.5184

Cámara-Leret, R., Schuiteman, A., Utteridge, T., Bramley, G., Deverell, R., Fisher, L., McLeod, J., Hannah, L., Roehrdanz, P., Laman, T., Scholes, E., de Fretes, Y., and Heatubun, C. (2019). The Manokwari Declaration: Challenges ahead in conserving 70\% of Tanah Papua's forests. Forest and Society, 3(1), 148-151. doi:http://dx.doi.org/10.24259/fs.v3i1.6067

Colfer, CJP \& Resosudarmo, IAP (eds) (2002). Which Way Forward: 'People, Forests, and Policymaking in Indonesia', Routledge, Washington, D.C.

Dressler, W., Büscher, B., Schoon, M., Brockington, D.A.N., Hayes, T., Kull, C.A., McCarthy, J. and Shrestha, K. (2010). From hope to crisis and back again? A critical history of the global CBNRM narrative. Environmental conservation, 37(1), 515.doi:https://doi.org/10.1017/S0376892910000044

Fatem, S. (2019). Connecting social forestry to conservation policies in Tanah Papua. Forest and Society, 3(1), 141-147. doi:http://dx.doi.org/10.24259/fs.v3i1.5865

Fisher, Micah R. (2019). "Beyond Recognition: Indigenous Land Rights and Changing Landscapes in Indonesia." University of Hawaii at Manoa,

Fisher, M. R., Moeliono, M., Mulyana, A., Yuliani, E. L., Adriadi, A., Judda, J., and Sahide, M. A. K. (2018). Assessing the new social forestry project in Indonesia: recognition, livelihood and conservation?. International Forestry Review, 20(3), 346361.https://doi.org/10.1505/146554818824063014

Fisher, R.J. (1995). Collaborative management of forests for conservation and development. IUCN Gland, Switzerland.

Galudra, G. (2019). Focusing on facilitation: Issues and challenges of capacity development in Indonesia's social forestry reforms. Forest and Society, 3(1), 133-136. doi:http://dx.doi.org/10.24259/fs.v3i1.5995

Gilmour, DA (2016), Forty years of community-based forestry: a review of its extent and effectiveness, Food and Agriculture Organization of the United Nations, Rome.

Kamoto, J., Clarkson, G., Dorward, P. and Shepherd, D. (2013). Doing more harm than good? Community based natural resource management and the neglect of local institutions in policy development. Land Use Policy, 35, 293301.doi:https://doi.org/10.1016/j.landusepol.2013.06.002

Lawrence, A. (2007). Beyond the second generation: towards adaptiveness in participatory forest management. CAB Reviews: Perspectives in Agriculture, Veterinary Science, Nutrition and Natural Resources, 2(28): 1-15.doi: https://doi.org/10.1079/PAVSNNR20072028

Lindayati, R. "Ideas and Institutions in Social Forestry Policy. Chapter 2 in Colfer, Carol J. Pierce, and Ida Ayu Resosudarmo (Eds.).(2002)." Which Way Forward? People, Forests, and Policymaking in Indonesia, 2002.

Lucas, A. and Warren, C. (2003). The State, the People, and Their Mediators: The Struggle over Agrarian Law Reform in Post-New Order Indonesia." Indonesia, 2003, 87-126.

Lund, C. (2016). Rule and rupture: state formation through the production of property and citizenship. Development and Change, 47(6), 1199-

1228.https://doi.org/10.1111/dech.12274

Massiri, S., Nugroho, B., Kartodihardjo, H., \& Soekmadi, R. (2019). Institutional Sustainability of a Community Conservation Agreement in Lore Lindu National Park. Forest and Society, 3(1), 64-76. doi:http://dx.doi.org/10.24259/fs.v3i1.5204

Maryudi, A. (2011). The contesting aspirations in the forests: Actors, interests and power in community forestry in Java, Indonesia. Universitätsverlag Göttingen.

Maryudi, A., Devkota, R. R., Schusser, C., Yufanyi, C., Salla, M., Aurenhammer, H., ... Krott, M. 
(2012). Back to basics: Considerations in evaluating the outcomes of community forestry. Forest Policy and Economics, 14(1), 1-5. doi:https://doi.org/10.1016/j.forpol.2011.07.017

McCarthy, J. (2000). The changing regime: Forest property and reformasi in Indonesia. Development and Change, 31(1), 91-129. https://doi.org/10.1111/1467-7660.00148

McDermott, MH, and Kate Schreckenberg. (2009). "Equity in Community Forestry: Insights from North and South." International Forestry Review, 11(2). 157-70.doi: https://doi.org/10.1505/ifor.11.2.157

Moeliono, M., Thuy, P., Waty Bong, I., Wong, G., \& Brockhaus, M. (2017). Social Forestry - why and for whom? A comparison of policies in Vietnam and Indonesia. Forest and Society, 1(2), 7897. doi:http://dx.doi.org/10.24259/fs.v1i2.2484

Myers, Rodd, Dian Intarini, Martua Thomas Sirait, and Ahmad Maryudi. (2017). Claiming the Forest: Inclusions and Exclusions under Indonesia's 'New'Forest Policies on Customary Forests. Land Use Policy, 66: 205-13. doi: https://doi.org/10.1016/j.landusepol.2017.04.039

Nuddin, A., Arsyad, M., Putera, M., Nuringsih, N., \& Teshome, T. (2019). Making the case for institutional support on designing agroforestry technology models for rehabilitating critical lands. Forest and Society, 3(1), 49-63. doi:http://dx.doi.org/10.24259/fs.v3i1.5975

Pratama, A., Supratman, S., \& Makkarennu, M. (2019). Examining forest economies: A case study of silk value chain analysis in Wajo District. Forest and Society, 3(1), 22-33. doi:http://dx.doi.org/10.24259/fs.v3i1.4912

RECOFTC (2011). RECOFTC's work is guided by the principles of clear and strong rights, good governance, and fair benefits for millions of forest-dependent people. https://archive.recoftc.org/basic-page/guiding-principles. Access on 16 April 2018

Ribot, J. C., Lund, J. F., \& Treue, T. (2010). Democratic decentralization in sub-Saharan Africa: its contribution to forest management, livelihoods, and enfranchisement. Environmental Conservation, 37(1), 35-44. https://doi.org/10.1017/\$0376892910000329

Safitri, M. (2015). Dividing the Land: Legal Gaps in the Recognition of Customary Land in Indonesian Forest Areas. Kasarinlan: Philippine Journal of Third World Studies, 16(30), 2.3148

Sahide, M. A. K., Fisher, M. R., Maryudi, A., Dhiaulhaq, A., Wulandari, C., Kim, Y. S., \& Giessen, L. (2018a). Deadlock opportunism in contesting conservation areas in Indonesia. Land use policy, 77, 412-424.doi:https://doi.org/10.1016/j.landusepol.2018.05.020

Sahide, M.A.K, Jusuf, Y., Alam, S., Supratman., Millang, S., Mahbub, A.S., Bachtiar, B., Sabar, A., Nasri., Nursaputra, A., Ahmad, M.F., Yahya, N.H. (2018b). Kajian Dampak Perhutanan Sosial di Provinsi Sulawesi Selatan. Fakultas Kehutanan Universitas Hasanuddin dan Balai Perhutanan Sosial dan Kemitraan Lingkungan Kementerian Lingkungan Hidup dan Kehutanan, Makassar, Indonesia.

Sahide, M. A. K., Supratman, S., Maryudi, A., Kim, Y. S., \& Giessen, L. (2016). Decentralisation policy as recentralisation strategy: forest management units and community forestry in Indonesia. International Forestry Review, 18(1), 78-95. https://doi.org/10.1505/146554816818206168

Salampessy, M., Febryano, I., \& Zulfiani, D. (2017). Bound by debt: Nutmeg trees and changing relations between farmers and agents in a Moluccan agroforestry systems. Forest and Society, 1(2), 137-143. doi:http://dx.doi.org/10.24259/fs.v1i2.1718

Suharjito, D., \& Wulandari, C. (2019). A reflection of Social Forestry in 2019: Towards inclusive and collaborative government approaches. Forest and Society, 3(1), 137-140. doi:http://dx.doi.org/10.24259/fs.v3i1.6099

Suhel, S., Bashir, A., \& Yuliana, S. (2019). Identifying the determining factors of recreation demand in Kongar Lake of South Sumatera: An individual travel cost approach. Forest and Society, 3(1), 34-48. doi:http://dx.doi.org/10.24259/fs.v3i1.5982

Supriyanto, B., Karyana, A., Tjiptono, B.H., Dwiyati, N., ....et al., (2018). Dampak Perhutanan Sosial Perspektif Ekonomo, Sosial, dan Lingkungan. Direktorat Jenderal Perhutanan Soial 
Kementerian Lingkungan Hidup dan Kehutanan, Jakarta

Sikor, Thomas. (2006) "Analyzing Community-Based Forestry: Local, Political and Agrarian Perspectives." Forest Policy and Economics 8, no. 4: 339-49.

Sikor, T \& Lund, C. (2009). 'Access and Property: A Question of Power and Authority', Development and Change, vol. 40, no. 1, pp. 1-22.

Sikor, T., He, J., \& Lestrelin, G. (2017). Property Rights Regimes and Natural Resources: A Conceptual Analysis Revisited. World Development, 93, 337-349. https://doi.org/10.1016/j.worlddev.2016.12.032

Tajuddin, T., Supratman, S., Salman, D., \& Yusran, Y. (2019). Bridging social forestry and forest management units: Juxtaposing policy imaginaries with implementation practices in a case from Sulawesi. Forest and Society, 3(1), 97-113. doi:http://dx.doi.org/10.24259/fs.v3i1.6049

Taylor, P. L. (2000). Producing more with less? Community forestry in Durango, Mexico in an era of trade liberalization. Rural Sociology, 65(2), 253-274. doi: https://doi.org/10.1111/j.15490831.2000.tb00028.x.

Tongkaemkaew, U., Sukkul, J., Sumkhan, N., Panklang, P., Brauman, A., \& Ismail, R. (2018). Litterfall, litter decomposition, soil macrofauna, and nutrient contents in rubber monoculture and rubber-based agroforestry plantations. Forest and Society, 2(2), 138-149. doi:http://dx.doi.org/10.24259/fs.v2i2.4431

Vandergeest, P \& Peluso, N.L. (2015). 'Political forests', in R Bryant (ed.), The International Handbook of Political Ecology, Edward Elgar Publishing, Cheltenham ; Northampton, MA, viewed 31 July 2017, http://www.elgaronline.com/view/9780857936165.xml

Wiersum, K. (2004). Social and community forestry, In: Encyclopedia of forest sciences. Elsevier, pp. 1136-1143. doi: https://doi.org/10.1016/b0-12-145160-7/00118-6.

Wiersum, K. F. (1997). Indigenous exploitation and management of tropical forest resources: an evolutionary continuum in forest-people interactions. Agriculture, ecosystems \& environment, 63(1), 1-16.doi: https://doi.org/10.1016/s0167-8809(96)01124-3.

Wulandari, C., \& Kurniasih, H. (2019). Community preferences for social forestry facilitation programming in Lampung, Indonesia. Forest and Society, 3(1), 114-132. doi:http://dx.doi.org/10.24259/fs.v3i1.6026

Zerner, C., (2000). People, Plants, and Justice: The Politics of Nature Conservation. Columbia University Press. 